\title{
The Differences Influence of Health Education Demonstration and Video Methods on Knowledge, Attitude, and Ability of Adolescent Practices about the Breast Self-Examination
}

\author{
Achmad Wahdi ${ }^{1}$, Dewi Retno \\ Puspitosari $^{2}$, Eppy Setiyowati ${ }^{2}$ \\ ${ }^{1}$ Master of Study Program of \\ Applied Nursing, Universitas \\ Nahdlatul Ulama Suarabaya, \\ Indonesia \\ ${ }^{2}$ Faculty of Nursing and Midwifery, \\ Universitas Nahdlatul Ulama \\ Suarabaya, Indonesia \\ Email: \\ achmadwahdi94@gmail.com
}

Received : October 5, 2020

Accepted : November 22, 2020

Published : November 30, 2020

This is an open-acces article distributed under the terms of the Creative Commons Attribution-ShareAlike 4.0 International License.

\begin{abstract}
Background: Breast self-examination is very important for women and it would be better if the teenagers already have the knowledge and practical ability to realize. Therefore breast selfexamination is very important to do in adolescents as early detection of breast cancer. The study aims to determine the differences in the influence of health education demonstration methods and video screenings on the knowledge, attitudes, and abilities of youth practice about BSE.

Methods: The research design used queasy-experimental, the population of the study at Darul Ulum 1 High School was 325 respondents, and a sample of 60 respondents (demonstration group $n=30$, video playback group $n=30$ ) were taken using the Stratified Random Sampling technique. Statistical tests using Wilcoxon and Mann Whitney with significance level $\alpha \leq 0.05$.

Results: The results showed there was an influence of health education demonstration and video playback methods on knowledge, attitudes, and practice abilities with a value of $\mathrm{p}=$ $0,000(p<\alpha)$, there were differences in the influence of health education demonstration methods and video playback on knowledge, attitudes and practice abilities with $\mathrm{p}$ value $=0.001$ $(\mathrm{p}<\alpha)$.

Discussion: Demonstration and video playback methods can improve knowledge, attitudes, and practice abilities compared to before being given treatment, so adolescents experience behavioral changes and expect health values to be well embedded, health status to be good, and finally teens able to be independent in health problems
\end{abstract}

Keywords: Practice Ability, Knowledge, Awareness, Attitude

Copyright ○ 2020 IIK STRADA Indonesia All right reserved. 


\section{INTRODUCTION}

Data in Indonesia from 237 million population, there are about 237,000 new cancer patients every year. Correspondingly, empirical data also shows that the prevalence of cancer increases with age. About $2.2 \%$ of deaths of all ages are caused by cancer. The prevalence of tumors/cancers in Indonesia is 1.4 per 1000 population (Angrainy, 2017). Along with the high incidence of breast cancer, the program that has been carried out by the Indonesian Ministry of Health based on data from the Directorate of Cancer Sub-Directorate for Non-communicable Diseases (PPTM), since 2007-2013 for early detection of suspect breast lumps (tumors) there are $1.68 \%$ of people (2.6 per 1000 population) while the target achieved in 2025 is $80 \%$. An increasing number of breast cancer sufferers occur due to a lack of knowledge and understanding of adolescents about breast self-examination (Pamungkas, 2011). Based on the results of a preliminary study conducted at Darul Ulum 1 High School Peterongan Jombang conducted on November 20, 2017, of 16 respondents there were 13 (81\%) respondents did not know how to do breast examination, and $3(19 \%)$ respondents who knew about how to do the self-breast examination, the attitude of respondents to the self-breast examination obtained as many as 3 respondents (19\%) have the attitude to agree to do routine breast examination routinely every month and 9 respondents $(56 \%)$ have a disagreement attitude has done by self-breast examination routine (19\%) 4 respondents $(25 \%)$ had a strongly disagreeing attitude carried out regularly by their breast examination.

Nowadays there are many breast cancer sufferers found at a young age, that not a few teenage girls aged fourteen suffer from tumors in their breasts. Where tumors that occur can become cancerous, if not detected early. Although not everything is malignant, this shows that there is now a trend of breast cancer symptoms that are getting higher in adolescence, therefore adolescents need to do breast self-examination early to prevent breast cancer (Lily, 2008 referenced in the Lubis, 2016). The impact is not carried out Breast self-examination that is adolescents can not know early about the symptoms of breast cancer (Nuryawati, 2014).

\section{METHODS}

The research design used queasy-experimental, the population of the study at Darul Ulum 1 High School was 325 respondents, and a sample of 60 respondents (demonstration group $n=30$, video screening group $\mathrm{n}=30$ ) were taken using Stratified Random Sampling technique. Statistical tests using Wilcoxon and Mann Whitney with significance level $\alpha \leq 0.05$.

\section{RESULTS}

1. Characteristics of Respondents and Homogeneity Table 1 Characteristics of Respondents and Homogeneity

\begin{tabular}{llcccc}
\hline \multirow{2}{*}{ No } & \multicolumn{2}{c}{ Variable } & \multicolumn{2}{c}{$\begin{array}{c}\text { Demonstration Method } \\
\text { Video Playback } \\
\text { Method }\end{array}$} \\
\cline { 2 - 6 } & & $\mathrm{N}$ & $\%$ & $\mathrm{~N}$ & $\%$ \\
\hline $1 \quad$ Age & 8 & 26,7 & 8 & 26,7 \\
& a. 15 years & 9 & 30,0 & 9 & 30,0 \\
& b. 16 years & 13 & 43,3 & 13 & 43,3 \\
\hline c. 17 years & & & & \\
\hline 2 & Ever Get Information breast & & & & \\
& examination & 28 & 93,3 & 18 & 60,0 \\
& a. Yes & 2 & 6,7 & 12 & 40,0
\end{tabular}


The Differences Influence of Health Education Demonstration and Video Methods on Knowledge.....

3 Time to Get Information

Breast self-examination
a. No
b. 1 year
c. 6 month
d. 1 month
10
6,7
33,3
e. 1 month
17
56,7
3,3
0,0

$\begin{array}{cc}12 & 40,0 \\ 9 & 30,0 \\ 8 & 26,7 \\ 1 & 3,3 \\ 0 & 0,0\end{array}$

\begin{tabular}{llccc}
\hline 4 Resources & & & & \\
a. TV/Radio & 2 & 6,7 & 12 & 40,0 \\
b. Mass media & 0 & 0,0 & 2 & 6,7 \\
c. Health workers & 5 & 16,7 & 6 & 20,0 \\
d. Friend & 16 & 53,3 & 8 & 26,7 \\
& 0 & 0,0 & 0 & 0,0 \\
\hline
\end{tabular}

Table 1 shows that the age of the demonstration method group nearly half of the respondents was 17 years old (43.3\%). Whereas in the video playback method group almost half of the respondents were 17 years old $(43.3 \%)$.

Based on table 1 number 2, it shows that the group of demonstration methods almost all respondents had received breast self-examination information (93.3\%). Whereas in the video playback method group most of the respondents had received breast self-examination information $(60.0 \%)$. Characteristics of respondents based on the time they got information on breast selfexamination 6 months ago in the demonstration method group, the majority were 17 respondents $(56.7 \%)$. Whereas in the video playback method group almost entirely never received breast selfexamination information of 12 respondents (40.0). Characteristics of respondents based on information sources from health workers in the demonstration method group were mostly 16 respondents $(53.3 \%)$. Whereas in the video playback method group rarely half were 12 respondents $(40.0 \%)$.

2. Special Data

1) Effects of Health Education Demonstration Methods and Video Screening on Adolescent Knowledge Before and After about breast self-examination

Table 2 Effects of Health Education Demonstration Methods and Video Screening on Adolescent Knowledge Before and After about breast self-examination

\begin{tabular}{|c|c|c|c|c|c|c|c|c|c|}
\hline \multirow[t]{3}{*}{ No } & \multirow{3}{*}{$\begin{array}{l}\text { Health } \\
\text { Education }\end{array}$} & \multicolumn{4}{|c|}{ Demonstration Method } & \multicolumn{4}{|c|}{ Video Playback Method } \\
\hline & & \multicolumn{2}{|c|}{ Pre } & \multicolumn{2}{|c|}{ Post } & \multicolumn{2}{|c|}{ Pre } & \multicolumn{2}{|c|}{ Post } \\
\hline & & $\mathrm{N}$ & $\%$ & $\mathrm{~N}$ & $\%$ & $\mathrm{~N}$ & $\%$ & $\mathrm{~N}$ & $\%$ \\
\hline 1 & Well & 11 & 36,7 & 30 & 100 & 3 & 10,0 & 20 & 66,7 \\
\hline 2 & Enough & 16 & 55,3 & 0 & 0 & 20 & 66,7 & 7 & 10,0 \\
\hline 3 & Less & 3 & 10,0 & 0 & 0 & 7 & 23,3 & 3 & 23,3 \\
\hline
\end{tabular}

Table 2 shows that the knowledge of respondents before being given health education in the demonstration method group mostly had sufficient knowledge of 16 respondents (55.3\%), after being given health education all had good knowledge of 30 respondents $(100 \%)$, and a p-value $(0,000<0,05)$, means that there is a significant decrease, can be seen from $p<0.05$. Whereas in the video playback method group before being given health education most had sufficient knowledge of 20 respondents $(66.7 \%)$, after being given health education most had good knowledge of 20 respondents $(66.7 \%)$, p-value $(0.001<0.05)$, means there is a significant decrease, can be seen from $\mathrm{p}<0.05$. This shows that $\mathrm{H} 0$ is rejected, which means there is an influence of health education demonstration and video screening methods on adolescent knowledge about breast selfexamination.

2) Effects of Health Education Demonstration and Video Screening Methods on Adolescent Knowledge Before and After about breast self-examination 
The Differences Influence of Health Education Demonstration and Video Methods on Knowledge.....

Table 3 Effects of Health Education Demonstration and Video Screening Methods on Adolescent Knowledge Before and After about breast self-examination

\begin{tabular}{|c|c|c|c|c|c|c|c|c|c|}
\hline \multirow[t]{3}{*}{ No } & \multirow{3}{*}{$\begin{array}{c}\text { Health } \\
\text { Education }\end{array}$} & \multicolumn{4}{|c|}{ Demonstration Method } & \multicolumn{4}{|c|}{ Demonstration Method } \\
\hline & & \multicolumn{2}{|c|}{ Pre } & \multicolumn{2}{|c|}{ Post } & \multicolumn{2}{|c|}{ Pre } & \multicolumn{2}{|c|}{ Post } \\
\hline & & $\mathrm{N}$ & $\%$ & $\mathrm{~N}$ & $\%$ & $\mathrm{~N}$ & $\%$ & $\mathrm{~N}$ & $\%$ \\
\hline 1 & Well & 10 & 33,3 & 27 & 90,0 & 4 & 13,3 & 18 & 60,0 \\
\hline 2 & Enough & 20 & 66,7 & 3 & 10,0 & 21 & 70,0 & 10 & 33,3 \\
\hline 3 & Less & 0 & 0 & 0 & 0 & 5 & 16,7 & 2 & 6,7 \\
\hline \multicolumn{2}{|c|}{ Wilcoxon Test } & \multicolumn{4}{|c|}{$\mathrm{p}=0,000$} & \multicolumn{4}{|c|}{$\mathrm{p}=0,004$} \\
\hline
\end{tabular}

Table 3 shows that the knowledge of respondents before being given health education in the demonstration method group mostly had sufficient knowledge of 16 respondents (55.3\%), after being given health education all had good knowledge of 30 respondents $(100 \%)$, and a p-value $(0,000<0,05)$, means that there is a significant decrease, can be seen from $p<0.05$. Whereas in the video playback method group before being given health education most had sufficient knowledge of 20 respondents $(66.7 \%)$, after being given health education most had good knowledge of 20 respondents $(66.7 \%)$, p-value $(0.001<0.05)$, means there is a significant decrease, it can be seen from $\mathrm{p}<0.05$. This shows that $\mathrm{H} 0$ is rejected which means that there is an influence of health education demonstration and video screening methods on adolescent knowledge about breast selfexamination.

3) Effects of Health Education Demonstration Methods and Video Screening on Adolescent Practice Capabilities After about breast self-examination

Table 4. Effects of Health Education Demonstration Methods and Video Screening on Adolescent Practice Capabilities After about breast self-examination

\begin{tabular}{|c|c|c|c|c|c|}
\hline \multirow[t]{3}{*}{ No } & \multirow{3}{*}{$\begin{array}{c}\text { Health } \\
\text { Education }\end{array}$} & \multirow{2}{*}{\multicolumn{2}{|c|}{$\begin{array}{c}\text { Demonstration Method } \\
\text { Post }\end{array}$}} & \multirow{2}{*}{\multicolumn{2}{|c|}{$\frac{\text { Demonstration Method }}{\text { Post }}$}} \\
\hline & & & & & \\
\hline & & $\mathrm{N}$ & $\%$ & $\mathrm{~N}$ & $\%$ \\
\hline 1 & Well & 26 & 96,7 & 19 & 63,3 \\
\hline 2 & Enough & 1 & 3,3 & 8 & 26,7 \\
\hline 3 & Less & 0 & 0 & 3 & 10,0 \\
\hline \multicolumn{2}{|c|}{ Mann Whitney Test } & \multicolumn{4}{|c|}{$\mathrm{p}=0,001$} \\
\hline
\end{tabular}

Table 4 shows that the practice ability of respondents after being given health education all had good practice ability of 19 respondents $(100 \%)$, and a p-value $(0.001<0.05)$, indicating that there was a significant decrease, seen from $\mathrm{p}<0.05$. Whereas in the video playback method group after being given health education most of them had good practice ability of 19 respondents $(63.3 \%)$, and the p-value $(0.001<0.05)$, showed that there was a significant decrease, it can be seen from $\mathrm{p}<0,05$. This shows that $\mathrm{H} 0$ is rejected, which means that there is an influence of health education demonstration and video screening methods on the ability of adolescent practice on breast self-examination.

4) Differences in the Influence of Health Education Demonstration Methods and Video Playbacks on Knowledge, Attitudes and Adolescent Practice Capabilities about breast selfexamination

Table 5. Differences in the Influence of Health Education Demonstration Methods and Video Playbacks on Knowledge, Attitudes and Adolescent Practice Capabilities about breast self-examination

\begin{tabular}{cccccccc}
\hline & & \multicolumn{5}{c}{ Method of Demonstration and Video Playback } \\
\cline { 3 - 7 } NO & Health & Method of & Video & Demonstration & Video & Demonst & Video \\
Education & \begin{tabular}{c} 
Demons- \\
tration and \\
Video \\
\cline { 1 - 6 }
\end{tabular} & Knowledge & Attitude & attitude & ration & Practice \\
& Playback & & & & Practices & \\
\hline
\end{tabular}


The Differences Influence of Health Education Demonstration and Video Methods on Knowledge.....

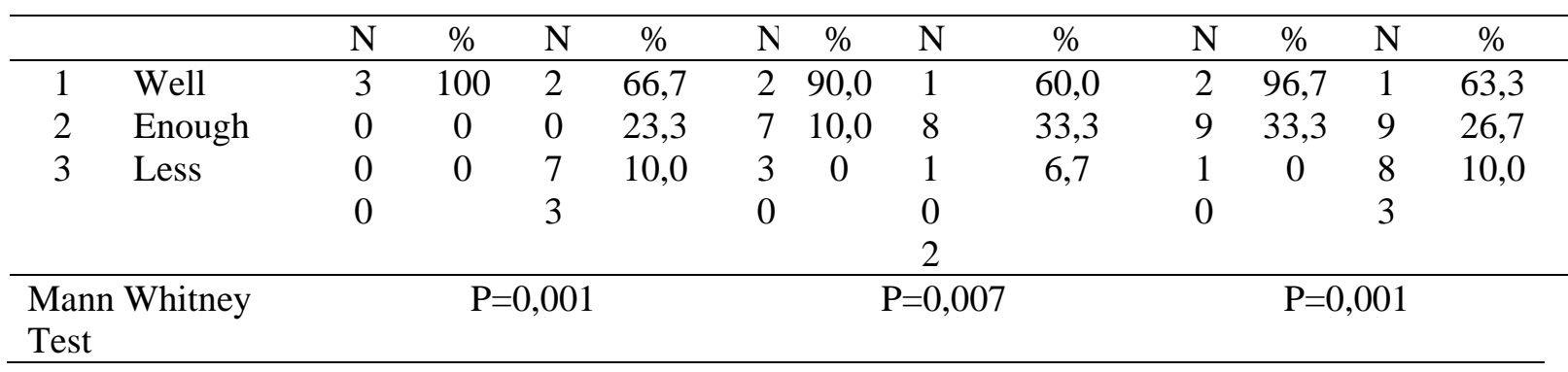

Table 5 shows the results of the Mann-Whitney test rank test. It can be seen that from the Mann-Whitney test in the knowledge category after the Demonstration Method and Video Screening the value is 0.001 which means $(\mathrm{p}<0.05)$, meaning that $\mathrm{H} 0$ is rejected and there are differences after being given health education Demonstration Method and Video Playback. Based on the results of the analysis of the Mann-Whitney rank test it can be seen that from the MannWhitney test in the attitude category after using the Video Demonstration and Playback Method pvalue of 0.007 which means $(\mathrm{p}<0.05)$, it means that $\mathrm{H} 0$ is rejected and there are differences after being given health education Demonstration and Video Screening.

Based on the results of the analysis of the Mann-Whitney rank test it can be seen that from the Mann-Whitney test in the category of practical ability after using the Demonstration Method and Video Playback the $\mathrm{p}$-value of 0.001 which means $(\mathrm{p}<0.05)$ means that $\mathrm{H} 0$ is rejected and there are differences after being given the Health Education Method Demonstration and Video Screening.

\section{DISCUSSION}

1) The Effect of Health Education Demonstration and Video Screening Methods on Adolescent Knowledge Before and After about Awareness

Based on table 2 shows that the knowledge of adolescents before being given health education in the demonstration method and video playback groups mostly have sufficient knowledge of 16 respondents $(55.3 \%)$, and 20 respondents $(66.7 \%)$, after being given health education in the demonstration method group all of them have good knowledge 30 respondents (100\%), in the video playback method group most of them have good knowledge 20 respondents (66.7\%). The results of the study indicate there is an influence of health education demonstration methods on knowledge with a $\mathrm{P}$ value $(0,000<0.05)$, there is an effect of health education video playback method on knowledge with a $\mathrm{P}$ value $(0.001<0.05)$.

Knowledge is the result of knowing, and this happens after people have sensed a certain object, sensing occurs through the five human senses, namely the sense of sight, hearing, smell, taste, and touch. Most human knowledge is obtained through the eyes and ears and influenced by many factors including education, age, environment, and information (Notoatmodjo, 2012).

The results showed that most of the insufficient knowledge in the demonstration method and video playback groups was due to the lack of knowledge of adolescents about the benefits and procedures of breast self-examination because there were no knowledge respondents had about the benefits and methods of breast self-examination both from the school environment, internet, magazines, brochures or mass media. There is no health education carried out at school to find out the benefits and methods of breast self-examination, because it is very important to be known by respondents. After all, the benefits and methods of breast self-examination are the most important part of breast self-examination. After being given health education in the demonstration method group, almost all of the knowledge was good because when health education was conducted on breast self-examination the respondents paid attention to the material presented. The demonstration method is a practical method for developing mental, physical, and technical aspects. While the video playback also increased most of the knowledge either because the method of video playback is alive or moving images that can be played many times and the results of the study there is also an influence.

2) Effects of Health Education Demonstration and Video Screening Methods on Adolescent Attitudes Before and After about breast self-examination 
Based on table 3 shows that the attitudes of adolescents before being given health education in the demonstration method group mostly had sufficient attitudes of 20 respondents (66.7\%), in the video playback method group most of them had sufficient attitudes of 21 respondents $(70.0 \%)$. After being given health education in the demonstration method group, almost all of them had a good attitude of 27 respondents $(90.0 \%)$, in the video screening method group most of them had a good attitude of 18 respondents $(60.0 \%)$. The results showed there was an effect of health education demonstration method on attitudes with a $\mathrm{P}$ value $(0,000<0.05)$, there was an influence on health education video playback methods on attitudes with a $\mathrm{P}$ value $(0.004<0.05)$.

Based on table 3 shows that the attitudes of adolescents before being given health education in the demonstration method group mostly had sufficient attitudes of 20 respondents $(66.7 \%)$, in the video playback method group most of them had sufficient attitudes of 21 respondents $(70.0 \%)$. After being given health education in the demonstration method group, almost all of them had a good attitude of 27 respondents $(90.0 \%)$, in the video screening method group most of them had a good attitude of 18 respondents $(60.0 \%)$. The results showed there was an effect of health education demonstration method on attitudes with a p-value $(0,000<0.05)$, there was an influence on health education video playback methods on attitudes with a p-value $(0.004<0.05)$.

3) Effects of Health Education Demonstration and Video Screening Methods on Adolescent Practice Capabilities After breast self-examination

Based on table 4 shows that the practice ability of adolescents after being given health education in the demonstration method group all have good practice ability 29 respondents (96.7\%), in the video playback method group most have good practice ability 19 respondents $(63.3 \%)$. The results showed there was an influence of health education demonstration methods and video playback on the ability to practice with a $\mathrm{P}$ value $(0.001<0.05)$.

According to Montessori (2015), one of the improvements in skills is influenced by the interests of students, where students are motivated to be able to detect breast cancer early and prevent death from breast cancer. The high interest of someone towards information that they have never heard of or obtained before, so someone will be more motivated in the process of providing counseling. They will pay close attention so that the information that has been given can be easily accepted by respondents. Interest influences someone to try or pursue something so that someone gains deeper knowledge and eventually the skills will also increase.

The results of previous studies also showed that it was proven effective in increasing the knowledge and practice skills of students about breast self-examination using lecture and demonstration methods (Hiwot Abera, 2017). Other research results also show that health promotion demonstration methods and breast self-examination skills can significantly influence (Milwati, 2015).

4) Differences in the Effects of Health Education Demonstration and Video Screening Methods on Youth Knowledge, Attitudes and Practical Abilities

Based on table 5 it can be seen that the results of the Mann-Whitney-marked rank test analysis can be seen that the knowledge of the demonstration method and video playback group P value of 0.001 which means $(\mathrm{p}<0.05)$ means that $\mathrm{H} 0$ is rejected and there are differences after being given health education demonstration methods and video playback. While the Mann-Whitney test on the attitude of the demonstration method and video playback group p-value of 0.007 which means $(\mathrm{p}<0.05)$ means $\mathrm{H} 0$ is rejected and there are differences after being given health education demonstration and video screening methods. And from the Mann-Whitney test on the ability of the group practice method of demonstration and video playback p-value of 0.001 which means $(p<0.05)$ means that $\mathrm{H} 0$ is rejected and there is a difference given the health education method of demonstration and video playback.

Audiovisual learning media are media that are used to help stimulate the senses of the eye (sight) and sense of hearing during the process of delivering information or education. While the demonstration method is a three-dimensional medium resembling its original form. Can be seen from the results of research obtained in both groups, an effective media for health education is a demonstration method. This is following the results of research on homogeneity tests that the average respondent had received more breast self-examination information on the demonstration 
method so that this caused the demonstration method to be very influential after the health education demonstration method was conducted, the respondents were more enthusiastic and invited to practice it real how to do a proper breast examination, to provide a better learning experience because it involves the sense of sight, hearing and touch. While the respondent's video playback method when playing the breast self-examination video many did not pay attention to the video.

The changes that will occur after being given health education include knowledge, attitudes, and skills. In essence, it can be in the form of emotions, knowledge, thoughts, desires, concrete actions from individual groups and communities. The advantage of demonstration methods using phantom teaching aids is that it can make the learning process clearer and more concrete, easier to understand something, adjust the theory to reality, and can do it yourself (Suliha cit Husnita, 2015). Thus health education is an effort or activity to help individuals, groups, or communities in improving both knowledge, attitudes, and skills to achieve healthy living (Induniasih, 2017). Health education is very necessary to instill health values early on in adolescents. Continued guidance in health education is very influential on changes in individual behavior, with efforts to provide health education continuously, it is expected that health values are well embedded, health status becomes good and finally, adolescents can be independent in health issues (Amanda, 2014).

\section{CONCLUSION}

Demonstration and video playback methods can improve knowledge, attitudes and practice abilities compared to before being given treatment, so adolescents experience changes in behavior and it is expected that health values are well embedded, health degrees become good and finally, adolescents can be independent in health problems.

\section{ACKNOWLEDGMENTS}

I say thank you to the headmaster of Darul Ulum 1 High School and the students who are willing to be respondents in this study.

\section{REFERENCE}

Angrainy, R (2017). Hubungan Pengetahuan, Sikap tentang Pemeriksaan Payudara Sendiri dalam Mendeteksi Dini Kanker Payudara pada Remaja. Journal Endurance (Volume 2. Nomer 2. June 2017). Diakses Tanggal 18 November 2017 Pukul 12:58.

Amanda, Rusmiyati, Elisa (2014). Pendidikan Kesehatan Teknik Menyusui dengan Benar terhadap peningkatan Kemampuan Menyusui pada Ibu Post Partum Normal di Rsud Dr. Seowondo Kendal. Jurnal Keperaatan dan Kebidanan. Diakses tanggal 08 November 2019 Pukul 05:04

Hiwot, A., Daniel, M., Asres, B. (2017). Effectiveness of Planned Teaching Intervention on Knowledge And Practice of Breast Self-Examination among first year midwifery students. Hawassa University. Diakes pada tanggal 19 Oktober 2019 Pukul: 13.19

Montessori, Y. (2015). Pengaruh Penyukuhan Payudara Sendiri (Pemeriksaan Payudara Sendiri) dengan Metode Demonstrasi terhadap Keterampilan Melakukan Pemeriksaan Payudara Sendiri. Yogyakarta: Sekolah Tinggi Ilmu Kesehatan Aisyiyah

Lubis, NL. (2014). Determinan Perilaku PEMERIKSAAN PAYUDARA SENDIRI Remaja Putri Dalam Upaya Deteksi Dini Kanker Payudara di Smk Negeri 8 Medan Tahun 2016: Universitas Sumatera Utara: Fakultas Kesehatan Masyarakat.

Nuryawati, SL. (2014). Studi Deskriptif Tingkat Pengetahuan Remaja Putri Tentang Periksa Payudara Sendiri. Diakses tanggal 18 November 2019 Pukul 13:53 